\title{
Communicating with Teens about Sex: Facts, Findings, and Suggestions ${ }^{1}$
}

\author{
Kate Fogarty and Carolyn H. Wyatt ${ }^{2}$ \\ This publication is one in a series of discussions \\ on understanding teen sexuality.
}

\section{Where do Teens get their Information about Sex?}

Although teens and parents may communicate cooperatively about certain topics, if you were to ask a group of 13-18 year-olds the question, "Do you discuss sex openly with your parents?" You may be surprised at the low number of "yes" answers you hear.

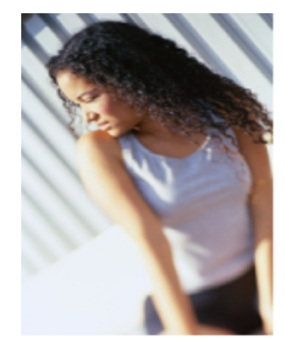

Teens mean different things when they say they talk openly about sex with their parents ${ }^{1}$. One definition of open communication is whether teens have conversations (rather than get lectured) with their parents about contraception, sexual behavior, and sexually transmitted infections/diseases
(STIs/STDs). Only half (50\%) of American teens have this type of conversation with their parents ${ }^{2}$. Forty percent of teens claim they talk with their parents about sex on a regular basis. ${ }^{3}$ This may be because parents of today's teens grew up during the sexual revolution, a time when teen sexual activity was much higher than that of generations before. Parents who grew up during the sexual revolution of the late 1960s through 1970s may be better able to communicate about sex based on their own values and past experience than they could have with their own parents who grew up before the sexual revolution.

Still, there's the 50-60\% of teens who don't discuss sex with their parents. If these teens are not talking with their parents about sex, then who are they talking to? Sex education should not just be the responsibility of schools, communities, or the media ${ }^{4}$. Middle schoolers ( $6^{\text {th }}$ to $8^{\text {th }}$ graders) want to learn more factual information in their sex education classes - as well as practical advice on how to apply the information they've learned ${ }^{5}$. Most parents $(95 \%$ in a study of 4,000 parents of school-aged youth) agree that responsibility for sex education should be shared by the school and the home ${ }^{6}$. Because school and community values may differ, the best sexual

1. This document is FCS2251, one of a series of the Family Youth and Community Sciences Department, Florida Cooperative Extension Service, Institute of Food and Agricultural Sciences, University of Florida. Publication date: October 2006. Visit the EDIS Web Site at http://edis.ifas.ufl.edu.

2. Kate Fogarty, assistant professor, Department of Family, Youth and Community Sciences, Cooperative Extension Service, Institute of Food and Agricultural Sciences, University of Florida, Gainesville, FL, 32611.

The Institute of Food and Agricultural Sciences (IFAS) is an Equal Opportunity Institution authorized to provide research, educational information and other services only to individuals and institutions that function with non-discrimination with respect to race, creed, color, religion, age, disability, sex, sexual orientation, marital status, national origin, political opinions or affiliations. U.S. Department of Agriculture, Cooperative Extension Service, University of Florida, IFAS, Florida A. \& M. University Cooperative Extension Program, and Boards of County Commissioners Cooperating. Larry Arrington, Dean 
health education begins at home. There are many benefits to parents and teens discussing sex including ${ }^{7}$ :

- Parents can communicate their own values on sexuality with their teens.

- Parents can better understand their teens perspective.

- Parents can tailor the information they share based on their understanding of their teenagers stage of development, life experience, personality, and knowledge level.

\section{Barriers to Parent/Adult-Teen Communication about Sex}

So, how do we explain the other half of teens who don't talk openly about sex with their parents? The main reason teens and parents or adults don't discuss sex is embarrassment ${ }^{8}$. Another reason is that parents think teens are more informed about sex than they actually are - and may even think that their teens know more about sex than they, as parents, do $^{9}$ ! Although teens tend to feel confident in what they know about sex, when tested, their actual knowledge is low ${ }^{10}$. Adolescents want to be treated as adults, but may feel talked down to when discussing sex with parents or other adults. Teens may not talk about sex with their parents because they see parents as close-minded, uncompassionate, or not clued in to the problems todays teens face ${ }^{11}$.

\section{Which Parents Talk with Teens the Most?}

Mothers are usually the ones who talk about sex with their teens and they tend to be "in charge" of these conversations - especially when they are communicating with their sons. The most interactive conversations, however, take place between mothers and daughters ${ }^{12}$. Teens are likely to disconnect when a parent or adult dominates the conversation because they feel overpowered. When teens disconnect from a conversation, they may withdraw from further discussions with their parents about sex. This communication gap reduces the number of parent-teen conversations about sex and may hurt the teen's knowledge of critical sexual health issues ${ }^{13}$.

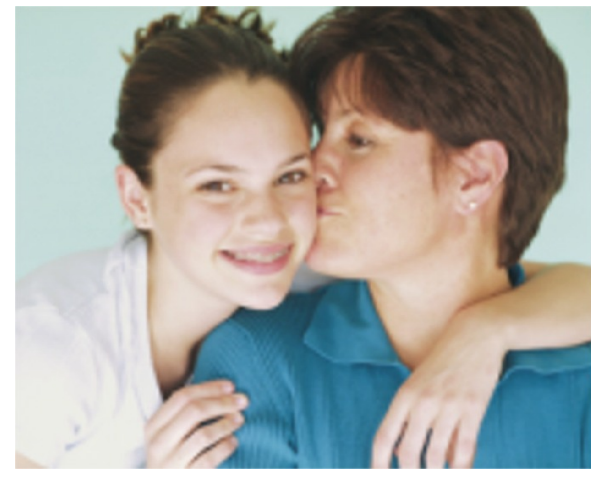

The Solution

Based on the limitations of adult-teen communication about sexual health, it is important to encourage positive communication between teens and adults in this area. Effective sexual health education programs for parents promote the following communication styles between parents and teens ${ }^{13}$ :

- having two-way conversations.

- using open-ended questions. (For example, "Tell me more about that...")

- having thorough discussions of dating and sexuality, including examples that represent parents moral values.

- showing empathy and reducing judgment.

Teens whose parents and other trusted adults practice the above communication styles, are more likely to ${ }^{13}$ :

- feel and act comfortable when discussing sensitive sexual matters with parents and others.

- seek out birth control and contraception, if they decide to be sexually active.

In addition, parent-school partnerships in sexual health education (for example assigning homework activities for youth to discuss sexuality issues with parents) are an effective means of preventing sexual risk behaviors and opening the lines of parent-teen communication $^{14}$.

School-based sex education involving communication "homework" with parents was shown to contribute to the following: 
- reducing early teens intentions to have sex before completing high school.

- increasing teens ability to refuse high-risk sexual behaviors.

- decreasing discomfort in parent-child communication about sex.

\section{Advice for Parents and Sexual Health Educators}

Ultimately, educating teens about sexuality needs to be a balance between what teens want to learn about and what we as adults feel they need to know to develop into healthy adults. Ways in which adults and parents can effectively communicate with and educate adolescents about sex include ${ }^{11,15}$ :

- encouraging open communication (speaking directly to teen).

- using accurate yet simple names for body parts, sexual behaviors, and feelings.

- using conversational skills such as open-ended questions, being nonjudgmental, disagreeing respectfully, making suggestions rather than directives ("you should").

- listening and speaking reflectively ("I messages", active listening, and turn-taking).

- keeping the communication going over time not having "the (one and only) sex talk."

- gently, but clearly, communicating parental values and moral expectations relating to sexual behavior.

- applying experiential learning to sexual health education (for example, (1) having youth list different sexual behaviors they have heard of, (2) guiding them to come up with examples of social/emotional, physical consequences and/or degree of life impact for each, and (3) asking them to come up with preventative solutions to these problems or consequences)

- encouraging teens to talk with adults they trust about sexuality.
- watching for danger signs such as sexual and other risk behaviors (unprotected sex, potentially harmful sexual relationships, depression, anxiety, self-mutilation behaviors)

- understanding that sexuality is a confusing topic teens face while struggling to understand themselves. Try to avoid stereotyping by gender or sexual orientation which could hurt teens developing sexual identities.

Overall, keep in mind that communicating effectively about sexuality with adolescents has important, positive long term benefits - those which promote teens physical, social, emotional and mental health.

\section{References}

1. Kirkman, M., Rosenthal, D., \& Feldman, S.S. (2005). Being open with your mouth shut: The meaning of openness in family communication about sexuality. Sex Education, 5, 49-66.

2. Jaccard, J., Dodge, T., \& Dittus, P. (2002). Parent-adolescent communication about sex and birth control: A conceptual framework. In S.S. Feldman \& D.A. Rosenthal (Eds.), Talking Sexuality:

Parent-adolescent communication (pp. 9-41). San Francisco: Jossey-Bass.

3. Caron, S.I., \& Moskey, E.G. (2002). Changes over time in teenage sexual relationships: Comparing the high school class of 1950, 1975, and 2000.

Adolescence, 37, 515-527.

4. Ward, L.M., \& Friedman, K. (2006). Using $\mathrm{TV}$ as a guide: Associations between television viewing and adolescents sexual attitudes and behavior. Journal of Research on Adolescence, 16, 105-131.

5. Byers, E.S., Sears, H.A., Voyer, S.D., Thurlow, J.L., Cohen, J.N., \& Weaver, A.D. (2003). An adolescent perspective on sexual health education at school and at home: II. Middle school students. Canadian Journal of Human Sexuality, 12, 19-34.

6. Weaver, A.D., Byers, E.S., Sears, H.A., Cohen, J.N., \& Randall, H.E.S. (2002). Sexual health education at school and at home: Attitudes and 
experiences of New Brunswick parents. The

Canadian Journal of Human Sexuality, 11, 19-30.

7. Kirkman, M. Feldman, S.S., \& Rosenthal, D. (2002). Talking to a tiger: Fathers reveal their difficulties in communicating about sexuality with adolescents. New Directions for Child and Adolescent Development, 97, 57-74.

8. Jaccard, J., Dittus, P., \& Gordon, V.V. (2000). Parent-adolescent congruency in reports of adolescent sexual behavior and in communications about sexual behavior. Child Development, 69, 247-261.

9. Radecki, C.M., \& Jaccard, J. (1995). Perceptions of knowledge, actual knowledge, and information search behavior. Journal of Experimental Social Psychology, 31, 107-138.

10. Berk, L.E. (2006). Child Development $\left(2^{\text {nd }}\right.$ Edition). Boston: Allyn \& Bacon.

11. Raffaeli, M., Bogenschneider, K., \& Flood, M.F. (1998). Parent-teen communication about sexual topics. Journal of Family Issues, 19, 315-333.

12. Lefkowitz, E.S., Sigman, M., \& Au, T.K. (2000). Helping mothers discuss sexuality and AIDS with adolescents. Child Development, 71, 1383-1394.

13. Blake, S.M., Simkin, L., Ledsky, R., Perkins, C., \& Calabrese, J.M. (2001). Effects of a parent-child communications intervention on young adolescents risk for early onset of sexual intercourse. Family Planning Perspectives, 33, 52-61.

14. Ponton, L.E. (2000). Teenagers and sexuality at camp: Understanding teen sexuality and tips for talking with them. Camping Magazine, September/October, 20-24. 